\title{
DIFFERENCES OF INHIBITION ZONE FOREST PURE HONEY AND CINNAMON (Cinnamomum burmani) AS ANTIBACTERIAL BACTERIAL COMPOUNDS OF MEMBERS OF THE Enterobacteriaceae FAMILY
}

\author{
Eko Naning Sofyanita ${ }^{a^{*}} ;$ Roni Afriansya ${ }^{b}$ \\ ${ }^{a, b}$ Department of Health Analyst ; Poltekkes Kemenkes Semarang \\ 115 Wolter Monginsidi street ; Semarang 50192 ; Indonesia
}

\begin{abstract}
Honey and cinnamon are plant products that have many properties, one of which is used as an antibacterial agent for various diseases. The effectiveness of the two active substances against bacteria in the Enterobacteriaeae family is unclear. The study was conducted to determine the differences in the effectiveness of forest honey and cinnamon in inhibiting the growth of bacteria in the Enterobacteriaceae family. This research method is an experimental study with a combination method of diffusion and wells using samples of the bacteria Klebsiella pneumoniae, Esherichia coli, Salmonella typhi, Serratia marcescens, and Enterobacter cloacae. Forest pure honey and cinnamon were prepared as test solutions with concentrations of $25 \%, 40 \%, 55 \%, 70 \%, 85 \%$ and $100 \%$. The results obtained were the inhibition zone formed on Nutrient Agar Plate (NAP) media, in forest pure honey the inhibition zone formed in S. typhi, E. coli, Klebsiella pneumoniae, Serratia marcescens, and Enterobacter cloacae was greater at $100 \%$ concentration, namely $30.5 \mathrm{~mm}, 32.5 \mathrm{~mm}, 38 \mathrm{~mm}, 29.5 \mathrm{~mm}$, $26 \mathrm{~mm}$, while the $100 \%$ concentration of cinnamon showed results, namely $12 \mathrm{~mm}, 10 \mathrm{~mm}, 8.5 \mathrm{~mm}$, $11 \mathrm{~mm}$, and $11 \mathrm{~mm}$. Conclusion is Forest pure honey was more effective at inhibiting bacteria from the Enterobacteriaceae family than cinnamon.
\end{abstract}

Keywords: forest pure honey; cinnamon; Enterobacteriaceae

\section{Introduction}

Typhoid fever is an infectious disease of the small intestine caused by $S$. typhi bacteria which enter the body through contaminated food and drinks (Lili Muselina, A. Fuad Afdhal, Ascobat Gani, 2004). Symptoms of typhoid fever include high fever, headache, nausea, increased body temperature, diarrhea, enlarged liver and spleen and loss of appetite. The Widal test is performed to diagnose typhoid fever. Research conducted by (Darmawati et al., 2011) on positive Widal blood cultures found Gram-negative stem bacteria members of the Enterobacteriaceae family, namely: Enterobacter cloacae, S. typhi, Serratia marcescens, Escherichia coli, Salmonella ssp., Klebsiella pneumoniae ssp. Ozanae and

\footnotetext{
*) Corresponding Author (Eko Naning Sofyanita)
}

E-mail: en.sofyanita@gmail.com
Gram-positive cocci are members of the genus Staphylococcus, namely: Stap. aureus, Stap. saprophyticus, Stap. xylosus, Stap. warnei, Stap. hominis, Stap. cohnii.

Bacteria belonging to the family Enterobacteriaceae are Gram-negative rod-shaped bacteria found in the large intestine of humans, animals, soil, water, and can be found in material decomposition. Bacteria members of the Enterobacteriaceae family are Escherichia sp., Shigella sp., Salmonella $s p$. ., Enterobacter sp., Klebsiella sp., Serratia sp., and Proteus sp. This group of bacteria is often found as contaminant bacteria in food and beverages and is the most common cause of infection (Hidayati, Ernin, Nuryati Juli, 2002). Bacteria members of the Enterobacteriaceae family play a role in the occurrence of typhoid fever apart from $S$. typhi so that the Widal test also obtained positive results. 
In typhoid fever, bacteremia occurs, so the basis of treatment is antibiotics. Treatment with appropriate antibiotics can reduce mortality. The efficacy of chloramphenicol in the treatment of typhoid fever has been recognized for its effectiveness. Other drugs such as ampicillin, amoxicillin and trimethoprim-sulfamethoxasole can also be used for the treatment of typhoid fever where the causative bacteria are resistant to chloramphenicol (Hariyati, 2010). The choice of other antibiotics that are effective, efficient, safe and inexpensive needs to be considered for alternative treatment steps such as the use of honey and cinnamon which are often used for the treatment of infectious diseases.

Honey is a thick liquid and is not only used as a natural sweetener, but is also used to help the healing process of various diseases, anti-oxidants, anti-flammers, eye disorders medicine and is used as an antibacterial (Hariyati, 2010). Scientifically, honey has been shown to contain organic compounds that are antibacterial. Several studies have stated that honey has antibacterial activity, such as research conducted (Darmawati et al., 2011) stated that honey is effective as an antimicrobial against Salmonella typhi bacteria in vitro and (Herawati et al., 2015) tested the antibacterial activity of honey against Staphylococcus aureus. Apart from forest pure honey, cinnamon plants are also often used as medicine with their ingredients, namely essential oils, safrole, sinamaldehyde, tannins, dammar, calcium oxalate, flavonoids, triterpenoids, and saponins. These essential oil components have activity as antibacterial activity for E. coli and Salmonella aureus(Balchin, 2006).

Therefore, it is necessary to conduct research on the differences of inhibition zone forest pure honey and cinnamon (cinnamomum burmani) as antibacterial bacterial compounds of members of the Enterobacteriaceae family.

\section{Method}

This research is an experimental study. The samples used in this study were Enterobacteriaceae bacteria, namely: Enterobacter cloacae, S. typhi, Serratia marcescens, Escherichia coli, Salmonella typhi., and Klebsiella pneumonia. samples obtained from culture bacteria conducted by (Darmawati et al., 2011).

The test solution used was forest pure honey and cinnamon with a concentration of $100 \%$ which is the raw material. Further dilution is carried out to make concentrations of $25 \%$, $40 \%, 55 \%, 70 \%, 85 \%$ and $100 \%$. The testing process was carried out with 2 repetitions of all concentrations.

\section{Preparation of Test Bacteria:}

Rejuvenation of Bacterial Culture

Colonies of Enterobacter cloacae, S. typhi, Serratia marcescens, Escherichia coli, Salmonella typhi., Klebsiella pneumoniae to be used in BHI (Brain Heart Infusion) media culture, incubated at $37^{\circ} \mathrm{C}$ for 24 hours, then cultured on Mac Concey and incubated at $37^{\circ} \mathrm{C}$ for 24 hours.

Preparation of Mc Farland Bacterial Suspension 0.5

Five tubes containing $5 \mathrm{ml}$ of sterile $\mathrm{NaCl}$ for each bacterium were prepared, namely Enterobacter cloacae, S. typhi, Serratia marcescens, Escherichia coli, Klebsiella pneumonia after which one end of the colony loop of each bacterium was taken from a pure culture that had been rejuvenated. Suspend into $5 \mathrm{ml}$ of sterile $\mathrm{NaCl}$ then compared with the Mc Farland turbidity standard of 0.5 .

The test method used a combination of diffusion and wells method to determine the zone of inhibition of forest honey and cinnamon against bacterial growth in the family Enterobacteriaceae. Pure suspension of each bacteria with the turbidity standard Mc. Farland 0.5 which has been prepared is then smeared using sterile cotton until evenly distributed on the surface of the NAP media with a thickness of $6 \mathrm{~mm}$ which has been made well and left for 10 minutes. A total of $100 \mu \mathrm{l}$ of test oceans were inserted into each well with a manufacturing concentration of $25 \%, 40 \%, 55 \%, 70 \%, 85 \%$ and $100 \%$ then incubated at $37^{\circ} \mathrm{C}$ for 24 hours with the petri plates not reversed so that forest pure honey does not spill. The resistance zone formed is measured in units ( $\mathrm{mm})$. Making positive control was done using chloramphenicol disc.

Data from all data from all experimental results were collected for analysis. All collected data were arranged in tabular form and described descriptively. The data obtained were then compared between the effectiveness of forest honey and cinnamon.

\section{Result and Discussion}

Data obtained from the inhibition zone of Enterobacter cloacae, S. typhi, Serratia marcescens, Escherichia coli, Salmonella typhi., Klebsiella pneumoniae on NAP media. All collected data 
were arranged in tabular form and described descriptively. The data obtained were then compared between the effectiveness of forest honey and cinnamon.

From the results of research on the inhibition power of forest honey and cinnamon on Nutrient Agar (NA) media against the growth of the bacteria Klebsiella pneumoniae, E. coli, S. typhi, Serratia marcescens, and Enterobacter cloacae using a combination method of wells and diffusion, each treatment obtained the power forest honey inhibition as shown in Table 1 and Table 2.

Table 1. Bacterial inhibition zone results on NA media after giving forest honey with a combination diffuse and wells method and incubated at $37^{\circ} \mathrm{C}$ for 24 hours

\begin{tabular}{lccccc}
\hline \multirow{2}{*}{ Concentration } & \multicolumn{5}{c}{ Inhibition zone (mm) } \\
\cline { 2 - 6 } & $\begin{array}{c}\text { K. } \\
\text { pneu }\end{array}$ & $\begin{array}{c}\text { E. } \\
\text { coli }\end{array}$ & $\begin{array}{c}\text { S. } \\
\text { typhi }\end{array}$ & $\begin{array}{c}\text { S. } \\
\text { marce }\end{array}$ & $\begin{array}{c}\text { Ent. } \\
\text { cloacae }\end{array}$ \\
\hline $25 \%$ & 14.5 & 15 & 26.5 & 17.5 & 15.5 \\
$40 \%$ & 15.5 & 18 & 29 & 21 & 16.5 \\
$55 \%$ & 17.5 & 20.5 & 31.5 & 23 & 19.5 \\
$70 \%$ & 23.5 & 29 & 32 & 25.5 & 22.5 \\
$85 \%$ & 27 & 31.5 & 35 & 26.5 & 24.5 \\
$100 \%$ & 30.5 & 32.5 & 38 & 29.5 & 26 \\
Chloram & 21 & 28.5 & 27 & 26 & 21 \\
\hline
\end{tabular}

Table 2. Results of bacterial inhibition zones on NA media after administration of cinnamon infusion

\begin{tabular}{lccccc}
\hline \multirow{2}{*}{ Concentration } & \multicolumn{5}{c}{ Inhibition zone (mm) } \\
\cline { 2 - 6 } & $\begin{array}{c}\text { K. } \\
\text { pneu }\end{array}$ & $\begin{array}{c}\text { E. } \\
\text { coli }\end{array}$ & $\begin{array}{c}\text { S. } \\
\text { typhi }\end{array}$ & $\begin{array}{c}\text { S. } \\
\text { marce }\end{array}$ & $\begin{array}{c}\text { Ent. } \\
\text { cloacae }\end{array}$ \\
\hline $25 \%$ & - & - & - & - & - \\
$40 \%$ & - & - & - & - & - \\
$55 \%$ & 3 & 4 & - & - & - \\
$70 \%$ & 5 & 5 & 8 & 7 & 6 \\
$85 \%$ & 5 & 7 & 8 & 7 & 6.5 \\
$100 \%$ & 8.5 & 10 & 12 & 11 & 11 \\
Chloram & 26 & 27 & 26 & 27 & 28 \\
\hline
\end{tabular}

The diameter of the inhibition zone can be seen in Table 1. The 100\% concentration of forest pure honey shows the largest average zone of inhibition in S. typhi, E. coli, Klebsiella pneumoniae, Serratia marcescens, and Enterobacter cloacae with a diameter of $38 \mathrm{~mm}, 32.5 \mathrm{~mm}, 30,5 \mathrm{~mm}, 29.5 \mathrm{~mm}$ and $26 \mathrm{~mm}$, while the $25 \%$ concentration of forest honey showed the smallest zone of inhibition in Klebsiella pneumoniae, E. coli, Enterobacter cloacae, Serratia marcescens, and S. typhi, namely $14.5 \mathrm{~mm}$, $15 \mathrm{~mm}, 17.5 \mathrm{~mm}, 15.5 \mathrm{~mm}$ and $26.5 \mathrm{~mm}$.
Cinnamon inhibition zone dimensions are based on Table 2. Data for S. typhi, E. coli, Klebsiella pneumoniae, Serratia marcescens, and Enterobacter cloacae at the highest concentration of $100 \%$, namely $12 \mathrm{~mm}, 10 \mathrm{~mm}, 8.5 \mathrm{~mm}, 11 \mathrm{~mm}$, and $11 \mathrm{~mm}$.

The zone of inhibition that is formed is due to the fact that forest pure honey has antibacterial and anti-inflammatory and antiviral properties. Forest pure honey is more natural than livestock honey because forest pure honey has a relatively low water content of less than $20 \%$ and a high sugar content, this condition inhibits bacterial growth because it causes an osmotic effect that can kill bacteria (Tonks, A. J., 2003). The ability of forest pure honey as another antibacterial is that it has a low $\mathrm{pH}$ level so that it is acidic which can inhibit bacterial growth, and has a large osmotic pressure and a high carbon to nitrogen ratio, besides that forest honey also has an antibacterial function because it can inhibit the growth of microorganisms through the hydrogen peroxide compound produced so that bacteria are difficult to grow (Rintiswati, Eko Winarsih and Ghazali Malueka, 2004). Forest pure honey has several main components, namely flavonoids, glycosids, and polyphenols. Research conducted by (Sholihah, 2013) showed that the results of phytochemical analysis tests of forest honey extract contained flavonoid and phenolic acid class compounds. And supported by the research of (Rintiswati, Eko Winarsih and Ghazali Malueka, 2004) showing that honey extract contains active compounds consisting of phenolic acid compounds and flavonoids which have anti-fungal properties.

According to (Manoi, 2009) the content of flavonoids functions as antibacterial by forming complex compounds against extracellular proteins that interfere with the integrity of bacterial cell membranes and the presence of flavonoid compounds, where pharmacologically flavonoid compounds function as anti-inflammatory, anti-oxidant, analgesic and anti-bacterial substances. Polyphenols are useful for breaking down enzymes, while glycosides have a high molecular weight produced by plants with an antibacterial action mechanism, namely reacting with porin (membrane trans protein) on the outer membrane of the bacterial cell wall, forming strong polymer bonds resulting in damage to porin which will reduce permeability. Bacterial cell membrane which will cause the bacterial cell to lack nutrition, so the 
bacteria will die (Rachawati, F., M.C. Nuria, 2010).

The higher the cinnamon extract concentration, the greater the antibacterial substance, so that the greater its ability to inhibit bacterial growth (Ajizah, 2004). In the inhibition zone assessment according to (Oti Wilberforce and Nkechinyere Olivia, 2017) the diameter of the zone of $\leq 5 \mathrm{~mm}$ is categorized as weak; inhibition zone $6-10 \mathrm{~mm}$ categorized as medium; inhibition zone $11-20 \mathrm{~mm}$ is categorized as strong, the zone of inhibition is $\geq 21 \mathrm{~mm}$ is categorized as very strong. this is due to the fact that Cinnamon contains antibacterial compounds such as essential oils, tannins, sapoin, and flavonoids.

The diameter of the resistance zone that is formed will be greater by increasing the active substances contained in forest honey. The diameter size of the formed inhibition zone is influenced by factors such as the turbidity of the bacterial suspense, the time of immersion of the bacterial suspension into Nutrient Agar (NA) media, incubation temperature, incubation time, agar thickness and media composition which greatly affect bacterial growth, diffusion. and forest honey activities, so that in conducting research must pay attention to these factors $(\mathrm{Wu}$ et al., 2019).

Based on the analysis, the results showed that forest honey with certain concentrations can inhibit bacterial growth. This is shown by the formation of an inhibition zone around the well containing forest honey on Nutrient Agar (NA) media that has been planted with bacteria. The negative control used was sterile distilled water with negative results (no zone of inhibition), while the positive control used was the Chloramphenicol Antibiotic, the inhibition zone diameter was obtained for E. coli, S. typhi, Serratia marcescens, Klebsiella pneumoniae, and Enterobacter. cloacae is $28.5 \mathrm{~mm}, 27 \mathrm{~mm}, 26 \mathrm{~mm} 21 \mathrm{~mm}$, and $21 \mathrm{~mm}$, this means that the bacterial isolates used in this study are still sensitive to chloramphenicol antibiotics.

The results of the research on cinnamon at a concentration of $20 \%$ and $40 \%$ did not show an inhibition zone, this could be due to the small amount of antibacterial substances and absorption in agar plates. So from these results it can be seen that forest pure honey will be more absorbent and have a greater inhibiting effect than cinnamon. The antibacterial properties contained in cinnamon can inhibit the growth of gram-negative bacteria by increasing the concentration of the test solution.
It can be interpreted that forest pure honey can inhibit the bacteria Klebsiella pneumoniae, E. coli, S. typhi, Serratia marcescens, and Enterobacter cloacae more effectively than cinnamon, this is in line with (Huda, 2013) who stated that honey can inhibit the growth of $S$. typhi bacteria. However, based on these data, forest honey cannot be used as a substitute for antibiotics in the treatment of positive Widal and only acts as a preventive or complementary antibiotic supplement in overcoming diseases caused by positive widal blood culture bacteria, namely Klebsiella pneumoniae, E. coli, S. typhi, Serratia. marcescens, and Enterobacter cloacae. This is because the diameter of the average inhibition zone produced by chloramphenicol antibiotics is much clearer or can kill bacterial growth compared to the average inhibition zone produced by forest pure honey, so it can be interpreted that forest pure honey can inhibit the growth of positive Widal blood culture bacteria but can't kill.

\section{Conclusion and Suggestion}

Forest pure honey is more effective at inhibiting the growth of bacteria in the Enterobacteriaceae family than the active ingredient of cinnamon and can be consumed as a companion to antibiotics and prevention of typhoid fever. From this research, it is hoped that further research can be carried out using a combination of forest honey and cinnamon. Further research is needed regarding the antibacterial effect against this type of bacteria other.

\section{Acknowledgments}

Thank you to the medical laboratory technology colleagues in the microbiology laboratory of the Muhammadiyah University of Semarang who have helped this research and Thank you to the colleagues of the Health Analyst Department of the Health Polytechnic of the Ministry of Health Semarang.

\section{References}

Ajizah, A. (2004) 'Sensitivitas Salmonella Typhimurium Terhadap Ekstrak Daun Psidium Guajava L .',Sensitivitas Salmonella Typhimurium terhadap Ekstrak Daun Psidiumguajava L, 1, pp. 31-38.

Balchin, M. L. (2006) 'Aromatheraphy science', London: Pharmaceutical Press, 1 Ed. 
Darmawati, S. et al. (2011) 'Keanekaragaman Spesies Bakteri pada Kultur Darah Widal positif Asal Kota Semarang Berdasarkan Karakter Fenotipik', pp. 496-501.

Hariyati, L. F. (2010) 'Aktivitas Antibakteri Berbagai Jenis Madu Terhadap Mikroba Pembusuk(Pseudomonas Fluorescens Fncc 0071, Dan Pseudomonas Putidancc 0070)', UPT Perpustakaan Universitas Sebelas Maret.

Herawati, D. et al. (2015) ‘Uji Aktivitas Antibakteri Beberapa Jenis Madu Terhadap Pseudomonas Aeruginosa Dan Staphylococcus Aureus Dengan Metode Difusi Agar', 2(1), Pp. 26-32.

Hidayati, Ernin, Nuryati Juli, dan E. M. (2002) 'Isolasi Enterobacteriaceae Patogen dari Makanan Berbumbu dan Tidak Berbumbu Kunyit (Curcuma longa L.) Serta Uji Pengaruh Ekstrak Kunyit (Curcuma longa L.) Terhadap Pertumbuhan Bakteri Yang Diisolasi', FMIPA Universitas Nahdlatul Wathan-Mataram Bandung.

Huda, M. (2013) 'Pengaruh Madu Terhadap Pertumbuhan Bakteri Gram Positif (Staphylococcus Aureus) Dan Bakteri Gram Negatif (Escherichia Coli)', JurnalAnalis Kesehatan, 2(1), pp.250-259.

Lili Muselina, A. Fuad Afdhal, Ascobat Gani, P. A. (2004) 'Pilihan Terapi Antibiotik untuk Demam Tifoid.Dalam: Update Management of Infectious Diseases and Gastrointestinal Disorders. Fakultas Kedokteran Universitas Indonesia Departemen Ilmu Kesehatan Anak.', Juni, 8(1), pp. 27-31.

Manoi, F. (2009) 'Warta Penelitian Dan Pengembangan Tanaman Industri', 15, p. 1.
Oti Wilberforce, J. O. and Nkechinyere Olivia, E. I. (2017) 'Phytochemical Screening and Antimicrobial Activity of Leaves Extracts of Mangifera indica and Carica papaya', International Journal of Current Microbiology and Applied Sciences, 6(8), pp. 3253-3259. doi:10.20546/ijcmas.2017.609.400.

Rachawati, F., M.C. Nuria, S. (2010) 'Uji

Aktifitas Fraksi Kloroform Ekstrak Etanol Pegangan (Cantella asiatica (L) Urb) seta Identifikasi Senyawa Aktifnya', Semarang, Universitas Wahid Hasyim.

Rintiswati, N., Eko Winarsih, N. and Ghazali Malueka, R. (2004) 'Potensi antikandida ekstrak madu secara in vitro dan in vivo', Berkala Ilmu Kedokteran, pp. 187-194.

Sholihah, J. (2013) 'Aktivitas Antibakteri dan Antioksidan Toga Jenis Madu Hutan Indonesia: Kehutanan Institut Pertanian Bogor.', Skripsi. Bogor.

Tonks, A. J., et al. (2003) 'Honey Stimulates inflammatory cytokine production from monocytes', Cytokine, 21(5), pp. 242-247.

Wu, K. et al. (2019) 'Mechanisms of vapor-phase antibacterial action of essential oil from Cinnamomum camphora var. linaloofera Fujita against Escherichia coli', Food Science and Nutrition, 7(8), pp. 2546-2555. doi: 10.1002/fsn3.1104. 